Article

\title{
Perception of Sustainable Development in a Local World Heritage Perspective
}

\author{
Else Ragni Yttredal and Nathalie Homlong * \\ Department of Public Administration and Planning, Volda University College, 6103 Volda, Norway; \\ else.ragni.yttredal@hivolda.no \\ * Correspondence: nh@hivolda.no
}

Received: 15 September 2020; Accepted: 20 October 2020; Published: 23 October 2020

\begin{abstract}
Many frameworks, theories and tools exist to help operationalize and comprehend the concepts of sustainable development and sustainability. However, knowledge about how the concepts are perceived at a local level is scarce. The objective of this paper is therefore to gain such insight and, through this, to contribute to the understanding of local sustainability dynamics. A study of perceptions of sustainability was carried out in Geirangerfjord, a UNESCO (United Nations Educational, Scientific and Cultural Organization) Natural World Heritage Site in Western Norway. Using semi-structured interviews, stakeholders were asked about their perceptions of what sustainable development in Geirangerfjord entails. Several methods of analysis were used, namely, theme analysis, emergent pattern analysis and group comparisons. Furthermore, an approach we call the "What Is Not There (WINT) analysis" was developed to identify themes that are part of the sustainability discourse, but that were not mentioned by stakeholders. Among the results of the analysis are that social dimensions of sustainability dominated the perceptions of stakeholders. Stakeholder perceptions are furthermore context-dependent and are formed by sustainability issues that are close to people's lives. The study also indicates that place of residence is a strong determinant of perceptions. In this way, the article adds to the existing literature on perceptions of sustainability.
\end{abstract}

Keywords: perception of sustainability; sustainable development; stakeholder groups; World Heritage Site (WHS); protected area tourism

\section{Introduction}

"A global agenda for change," nothing less, was what the UN (United Nations) World Commission on Environment and Development was asked to formulate when they started their work in 1983 [1]. In what has later been called "Our Common Future" or the Brundtland report, the Commission defines and describes sustainable development, a concept that has since become a paradigm of change all over the globe. More than 30 years later, the world is still struggling to achieve sustainability. Following from the global interdependence of sustainable development is the fact that it can only be achieved through the change of perceptions, beliefs and actions of individuals, groups and communities all over the globe. Actions on a small scale add up to the global totality, and stakeholders in local communities are thus important actors [2,3].

It has been argued that there is an overarching agreement about the content of the term "sustainable development" [4]. A balance between the social, economic and natural domains, and intergenerational equity are generally perceived to constitute the main elements of such a development $[5,6]$. However, others point to the fact that the concept is socially and politically constructed, and that perceptions therefore logically will vary [7-9]. Human perception is about individuals and groups making sense of the world. The perception process includes a complex interplay between objects, human senses and the brain. The details of the process are yet to be understood [10-12]. What is known is that 
perceptions are influenced by, for instance, physical conditions, cognitive capacities and context $[10,13]$. It is thus to be expected that perceptions differ. Empirical studies strengthen this argument, showing that the perceptions of sustainability among stakeholders differ between geographical levels, different segments of society and depending on personal situations $[8,9,14-16]$. Studies about perceptions of sustainability are, however, scarce. The same applies to studies of the relationship between perceptions of sustainability and sustainable behavior. There is, however, a broad line of literature looking into the relationship between attitudinal variables like values, beliefs and norms, and sustainable or environmental behavior [17]. Since these variables interplay with perceptions, we also draw on this line of literature to discuss how perceptions of sustainability may influence behavior.

We acknowledge that there is a complex interplay between diverse factors to explain sustainable behavior, and we are not aiming at investigating these to their full extent. The objective of this paper is to gain insight into perceptions among local stakeholders about the concept of sustainability. Such insights form a basis for the understanding of sustainable and unsustainable actions on the local level. Geirangerfjord, a UNESCO (United Nations Educational, Scientific and Cultural Organization) Natural World Heritage Site (NWHS) in Western Norway, serves as a case study. Given the so far scarce literature on perceptions of sustainability, we have used an inductive approach to data collection and analysis.

As one of Norway's most visited destinations, especially within the segment of nature-based tourism, Geirangerfjord is an icon of Norwegian tourism. Pre-COVID (coronavirus disease)-19 numbers show that 235 inhabitants were hosting just below one million visitors a year (2018) [18]. Sustainable development has thus been high on the agenda. A NWHS represents the globe's most valuable natural areas. Especially in these places, knowledge about inhabitants' and other stakeholders' perceptions of a sustainable community development is important if sustainable policies are to succeed.

This article will first give a general introduction to the concept of sustainability and research on perceptions, perceptions of sustainable development, and research on sustainable behavior. We then continue to present the study area, methods of data collection and analysis, followed by the results. We discuss the findings in the light of the literature. Conclusions and implications of the findings are presented at the end.

\section{Literature Review}

The concept of sustainability did not emerge in a vacuum in 1987. As a way of thinking, it has been part of religious teachings, medieval philosophies and traditional beliefs for centuries [19-21]. The UN report "Our common future," however, gave "sustainable development" and "sustainability" content and political credibility, defined as:

"1. Sustainable development is development that meets the needs of the present without compromising the ability of future generations to meet their own needs. It contains two key concepts:

- the concept of 'needs', in particular the essential needs of the world's poor, to which overriding priority should be given; and

- the idea of limitations imposed by the state of technology and social organization on the environment's ability to meet present and future needs." (Section 2.1)

Ever since, the concept of sustainable development has been central in the discourse of future developments and has received varied contents and definitions, both in academia and in politics [4,19,22-26]. By 2015, the UN General Assembly adopted the Sustainable Development Goals (SDGs) aimed at serving as guiding principles for future global developments. With 17 goals and more than 100 sub-goals, the SDGs cover almost all aspects of human life [6].

Various concerns have been raised about the concept-that it is vague, that it attracts hypocrites, that it is in danger of fostering delusions, and that there is a potential for emphasizing individual aspects rather than the whole $[7,19,27]$. Despite these concerns, there seems to be a general agreement 
on many aspects of the content, including inter- and intra-generational equity, the protection of natural resources, and balancing development economically, socially and ecologically. It is also argued that the consensus on goals and process goes way beyond these more general terms [4].

\subsection{Perceptions}

To serve as global goals and to guide future development, sustainable development needs to be perceived, interpreted and acted upon in a consistent and coherent way in different geographical settings and contexts. Given the complexity of the concept, this is not a straightforward precondition. Defined as "the process or result of becoming aware of objects, relationships, and events by means of the senses"[28], human perceptions are highly complex.

The process of perception has been subject to scrutiny from Plato onwards within as diverse fields as philosophy, neuroscience, psychology and communication [29]. Physiologically, perception is about the interplay between sensory information like vision, hearing and touch and the brain [13]. The perception process, however, is to a large extent unconscious and involves cognitive processes $[11,29,30]$ in selecting, organizing and interpreting stimuli. Such a perception process involves several parts of the brain and complex neurology. Even with steadily more sophisticated methodology, the exact physiology of perception is still an enigma $[12,13]$.

Perceptions are influenced by a number of factors [31]. Physical location and orientation of the body is one such factor [10], context and information environment are others [29]. Tversky and Kahneman [32] also showed that choices between alternatives are highly influenced by the framing of the problem. It is widely recognized that perceptions are also influenced by characteristics of the individual [33]. Factors individuals bring into the situation, such as experience, background, knowledge level, beliefs, attitudes, values and personal preferences influence the process of perception [10,13,29]. For instance, Dunham and Banaji [29] claim that objects are not perceived as they are, but are partially constructed and interpreted out of what is already inside our minds.

Attention is another factor widely presumed to influence the perception process [34,35]. Humans tend to miss information that they do not expect. They also fail to see what they are looking at, unless attention is directed at it [35]. Lueg [10] argued that "failing to notice information that could be relevant to a task at hand is not an exception but rather to be expected." The reasons for this are cognitive and perceptual systems that have evolved to perceive only a fraction of the information available.

\subsection{Perceptions of Sustainable Development}

Literature on perceptions of sustainable development is scarce. Robinson [7] found that "one of the most striking characteristics of the term sustainable development is that it means so many different things to so many different people and organizations." Macnaghten et al. [8,9] had several interesting observations in this regard. They found in a study of perceptions of sustainability in Lancashire, England, that environmental concerns are largely expressed in local terms like beach pollution, litter and dog mess. They also found that day-to-day concerns are important, most prevalent in the form of job insecurity or unemployment. They explained this phenomenon not with ignorance about the global issues of climate change or by a lack of concern, but rather by the perceived intractability of the global problems for local residents, and lack of trust in information providers. With this comes a lack of sense of agency, a felt inability to influence the situation. In their discussions, Macnaghten et al. [9] also found that people in most population groups express a strong identification with local place, especially related to their immediate communities. Pearson [36] pointed to the fact that the perceptions of the problems related to sustainability are an issue of scale and agency. In the example of land management, perceptions differ greatly from farmers to global actors. Principal agents also change depending on administrative and geographical levels. Pearson argued that approaching sustainability thus should be done from the bottom up in participatory processes: defining the problem and then finding ways to solve the particular problem. He also argued that the perceptions of sustainability are fluent in time and influenced by risk. 
Related to the themes of locality and attachment, O'Toole et al. [15] pointed out that perceptions of sustainability are dependent on geography and scale. In their study, they found that perceptions of sustainable development differ depending on the experience of local residents. For instance, in communities where populations are in decline, population growth is an important issue related to perceptions of social sustainable development. Where there are concerns about employment, employment is an important ingredient in a sustainable future. These findings are supported by Jones et al. [37], who found that local residents rated employment as the most important factor for sustainable development in their community. Tiani and Charnacle [38] underlined that there is a certain agreement across different stakeholder groups about the criteria of sustainability, but that there are differences in the weighting of issues. These studies thus show that sustainability issues need to be contextualized.

Literature touching on perception of sustainability more indirectly shows that lack of involvement and perceived benefits of the local stakeholders is perceived to negatively influence attitudes toward nature conservation and protected areas [14,39]. Research suggests that economic incentives motivate people to become committed to the environment and conservation, particularly in remote protected areas [14,40,41]. In a study in a tiger reserve in India, Sekhar [42] found that a majority of the residents who experienced economic benefits from tourism also had positive attitudes towards tourism and nature conservation. Sekhar also emphasized the importance of including the local population in management planning, and of ensuring that residents get a fair share of tourism income. Also, Sirivongs and Tsuchiya [43], in a survey conducted among residents of a Natural Protected Area in Lao, showed that residents' willingness to participate in protection of a natural forest area was closely tied to local participation and economic benefits from tourism.

\subsection{Environmental Beliefs, Attitudes and Values-And Sustainable Behavior}

While research into the effect of perceptions on sustainable behavior is scarce, there is a wide range of research aimed at comprehending the relationship between attitudinal factors like beliefs, values and norms and environmental behavior. As perceptions are influenced by and influence these factors in a complex interplay, this line of literature is also relevant for the understanding of the relationship between perceptions and behavior.

Environmental beliefs may be divided into three groups: an anthropocentric approach based on the instrumental value of the environment for human beings (humans above nature), a biospheric approach that values the environment for its own sake (natural balance), and an ego-bio-centric approach that values human beings within nature as a whole [44-46]. Imran et al. [14] investigated these beliefs, comparing different stakeholder groups, namely, protected area authorities, local communities, tourists and tourism enterprises. They found that the first two groups have a significantly higher eco-centric interest in the environment, but that there is a complex mix of ecological orientations among the stakeholders, depending again on a complex mix of contextual factors. Their results support Macnaghten et al. [9] and O'Toole's [15] findings that context is important in understanding perceptions of sustainability. Furthermore, they found a tendency among all stakeholder groups to endorse pro-ecological values, but that these values were not of top priority.

There are also numerous studies assessing how environmental attitudinal factors influence behavior $[14,44,45,47]$. This relationship is not straightforward. In environmental psychology, Stern et al. [44] have developed the value-belief-norm (VBN) theory to explain environmental behavior. They point to the fact that environmentally significant behavior can be divided into different groups: activism, private-sphere environmentalism, and non-activist public-sphere behavior. They show that these different types of behavior depend on different mixes of values and beliefs. Another example of this complex relationship between attitudes and behavior stems from business and marketing literature on sustainability. In this line of literature, the "attitude-behavior gap" is widely known. Consumers in general, and tourists in particular, are concerned with environmental issues and have intentions of environmentally friendly behavior. There are, however, huge gaps between intentions and what people actually do when in a situation of choice. In a bibliographical study on environmentally friendly 
tourism behavior conducted by Juvan and Dolnicar [48,49], a large proportion of tourists expressed a pro-environmental attitude, but they found that the category of tourists both intending to and actually performing environmentally friendly behavior varied between $2 \%$ and $20 \%$, much depending on the methodology of the research.

A line of research studied the relationships between environmental connectedness and environmental behavior. Arnberger et al. [50] looked into the relationship between the affinity for an Austrian national park by visitors and their attitude towards nature conservation and visitor management measures. Greater affinity went hand in hand with more positive attitudes. Also, two studies conducted among residents in or near protected areas in Italy showed that positive regional identity of the respondents was linked to higher support for protection [51]. In line with this, Davis et al. [52] conducted two studies about environmental connectedness and commitment to the natural environment among students at a university in the United States. The studies showed that higher commitment predicted higher levels of pro-environmental behavior.

Studies trying to explain pro-environmental behavior have diverse starting points, diverse dependent variables and they also use concepts in different ways. Through a thorough literature review, McDonald [17] constructed an integrated framework aimed at understanding the complex relationship among different factors leading to pro-environmental employee behavior in the work place. She found that influencing variables may be divided into four categories: 1 . Intrapersonal factors like demographics, attitudes, habit and values; 2 . Motivational factors like work satisfaction, intrinsic and extrinsic motivation; 3 . Interpersonal or social factors like social norms and self-identity; and 4. External factors like facilitating conditions and organizational factors. The factors do not necessarily have a direct effect on environmental employee behavior, but are to a large extent mediated by other factors.

\section{Materials and Methods}

\subsection{Study Area}

As can be seen in Figure 1, Geirangerfjord is located in Western Norway. In 2005, the area was inscribed on the UNESCO World Heritage List together with Nærøyfjord as the "West Norwegian Fjord Landscape." Pre-COVID-19 figures show that just below 1 million tourists visited the narrow valley each year mainly during the summer months of June, July and August. Cruise tourism contributes roughly to one third of these visitors [18]. Only 235 people live year-round in the village of Geiranger [53]. Agriculture has traditionally been the livelihood of people living there. However, having a more than 100 years long history of tourism, the sector now provides employment to most people in the village, either directly or indirectly. Year-round settlement in Geiranger is totally dependent on tourism.
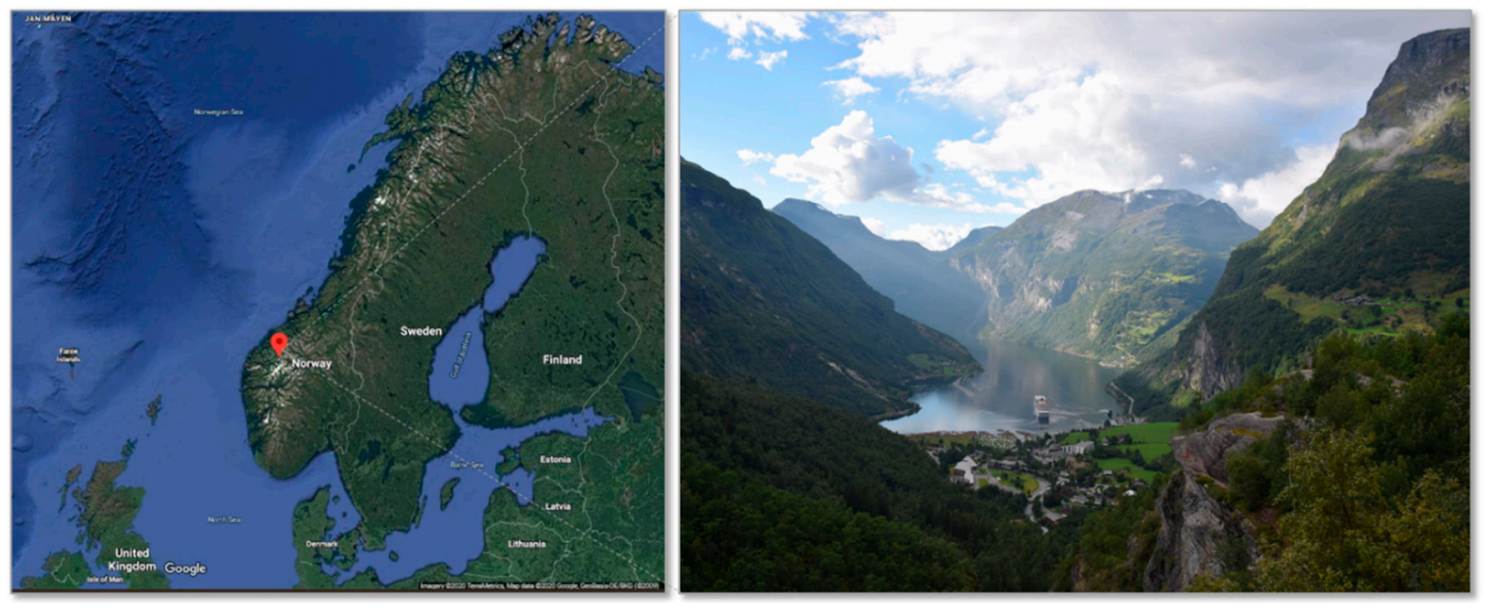

Figure 1. The Geiranger area on the west coast of Norway. (Map: Imagery (C) 2020 TerraMetrics, Map data (C2020 Google, GeoBasis-DE/BKG (C2009)) (Photo: Nathalie Homlong). 
As an icon of tourism, there have been ongoing debates in, around and about the Geiranger World Heritage Area. Crowding and congestion have, during the study period and prior to COVID-19, been issues of complaint and debate. Smog in the air over the Geirangerfjord, witnessing poor air quality, has been another. Both issues have contributed to research and debates on sustainable development and solutions [54-60]. The local World Heritage administration has been an important actor, pushing the process forward. The discourse has reached regional and national decision makers and has been a matter of national concern [58]. In 2018, the national assembly adopted a law allowing only tourist ships and ferries with zero emissions to enter the fjord from 2026 [61].

\subsection{Data Collection}

The main set of data for this study was collected through 23 semi-structured stakeholder interviews and 8 responses from a questionnaire with the same open-ended questions. The period of data collection was fall 2017 to spring 2018. The information from the data collection was supplemented by document studies and participation in meetings related to ongoing discussions on environmental, social and economic issues in the area. Discussions about these issues, relevant studies carried out in the region, as well as international literature on sustainability formed the basis for the creation of the interview guide and the questionnaire. Stakeholders for the interviews were identified based on Freeman's [62] broad definition of stakeholders as all who are affected or are affecting an organization. Our definition was thus formulated as "any group or individual who can affect or is affected by the transport system in the Geiranger area as it is today, or changes to it." The reason for the wording of the definition was that the entire project this study is connected to was about the sustainability of the tourist transportation system in the area. Knowledge about stakeholders' perceptions of sustainability was thus essential.

An initial list of more than 200 stakeholders was made and grouped before picking informants for a first round of 9 interviews. The aim of this preliminary phase was to identify major stakeholders, to add missing stakeholders, and to understand how various stakeholders affect or were affected by the transport system. Following from this, a short-list of 40 main stakeholders along three dimensions was developed: 1. Place of residence-local versus non-local; 2 . Whether they were mainly affected by or rather affected the transport system; and 3. Whether they represented the categories of inhabitants without direct economic interest in tourism, public authorities, nature conservation, tourism businesses, or other. The main bulk of interviewees were inhabitants of, or closely connected to, the area. The interviews were conducted face to face or by telephone. Transcripts and/or recordings were made. The interview guide raised different themes, with perceptions of the transport system and sustainability being the main issues. In addition to the main themes, information on the interviewee's personal and organizational background and interests in the matter was recorded and used in the analysis. Several questions regarding sustainability were used in the interviews. The main question for this analysis was an open question about what sustainable development of Geirangerfjord and surrounding areas entailed for the interviewees. This open question was followed up by an encouragement to address economic, social and environmental factors. Furthermore, the interviewees were asked what they perceived to be main challenges to sustainable development for the area. Interviews were halted at 23 , when it seemed that little new information was gained from additional interviews. Themes from the 8 questionnaires with open-ended questions overlapped with the themes from the interviews and helped to confirm that data saturation had been reached.

\subsection{Data Analysis}

NVIVO software (QSR: Burlington, MA, USA) was used to store and analyze the data. Several approaches were used in the analysis. Firstly, an inductive approach was used for coding of themes. After several rounds of coding and grouping of different thees, main themes were identified. Secondly, we looked for emergent patterns across themes [63]. Memos, including notes on specific findings were created as a starting point. Findings in the memos were then further elaborated through a second round of coding of the data. Thirdly, we used stakeholder attributes to compare perceptions between 
stakeholder groups by importing an Excel sheet with background variables to NVIVO. The data were then again analyzed with the aim of looking for differences and similarities across, for instance, geographical boundaries, roles and sectors. Themes in the text were also counted.

The fourth and last approach used was developed during the process and called the "What Is Not There (WINT) analysis." The approach needs further elaboration. Discourse analysis in the linguistic tradition reveals that not only what is explicitly communicated is significant, so are also, for instance pauses, vocalization or issues that are not there [64]. Critical discourse analysis, in addition, points to the fact that themes left out of a discourse highlight power relations [65]—referring to writers like Foucault [66] and Lukes [67]. We are following a discourse analysis tradition, using what is present in the interviews also to identify what is not there. We do this by contrasting the data to what is known to be part of sustainability discourses locally and globally. Are the official definitions of the concept, including intergenerational equity and the balance of social, economic and ecological systems represented? Are global concerns, like climate change and discourses on waste, prominent in the interviews? Is the local and national discourse on air quality present? Contrasting the data in this way brings up interesting new perspectives on perceptions. However, in the WINT analysis, we do not go all the way to analyzing the interviews in a power perspective or in a linguistic sense.

The different approaches to data analysis are presented in Table 1.

Table 1. Approaches to data analysis in the study schematically presented. Source: own table.

\begin{tabular}{ccc}
\hline Method of Analysis & Unit of Analysis & Main Question Raised in Analysis \\
\hline Theme analysis & All stakeholders & $\begin{array}{c}\text { What are the stakeholders' main } \\
\text { perceptions and concerns? }\end{array}$ \\
\hline Emergent pattern analysis & All stakeholders & $\begin{array}{c}\text { Do the stakeholders' perceptions form } \\
\text { into patterns or relations of themes, or } \\
\text { even into a specific logic? }\end{array}$ \\
\hline WINT (What Is Not There) analysis & All stakeholders & $\begin{array}{c}\text { Which themes emerge when comparing } \\
\text { what is in the data to what is expected } \\
\text { to be there? (In this case, contrasting the } \\
\text { findings to knowledge about local and } \\
\text { global sustainability discourses) }\end{array}$ \\
\hline Stakeholder group comparison & Stakeholder groups & $\begin{array}{c}\text { Are there similarities and differences of } \\
\text { themes and patterns across groups? }\end{array}$ \\
\hline
\end{tabular}

\section{Results}

The presentation of results, related to perception of sustainable development, are structured by the methods of analysis presented in the preceding section. Firstly, the main themes are introduced. Secondly, emergent patterns found during the analysis are presented [63]. Thirdly, looking for missing themes and patterns, in the perspective of prevailing perceptions of sustainability are introduced (WINT analysis). Finally, similarities and differences related to these themes, patterns and missing themes are compared across stakeholder groups using place of residence and professional roles as dividing lines.

\subsection{Main Themes}

There are two main themes presented by the stakeholders when asked about what they perceive sustainable development in the area entails. The first theme, about settlement, addresses the social aspect of sustainability. The second theme, traffic, can also be described as mainly social, but touches upon environmental aspects. 


\subsubsection{Increase in the Number of Inhabitants in the Community}

There is a strong trend of urbanization in Norway, a fact that is widely documented in statistics and publications [68]. This development leaves rural areas and villages with steadily shrinking populations. This is also the case for the Geiranger area. The most prominent and recurring theme in the interviews is thus increasing settlement. Sub-themes related to this main theme differ. One of the issues is the maintenance of basic public services like school and kindergarten, but also social activities like choirs and sports. A local businessperson living in the Geiranger area expresses it like this:

"We want people to live here, have children in school and kindergarten. This is important for the future. We are almost down to $20 \mathrm{kids}$ from 1st to 10th grade here (in school). (The problem is) ... the municipality, finances, no residential plots... When people are not able to build houses, they move, there are no houses for sale, they are inherited by (outside) relatives." (Interview with local businessperson, own addition in brackets)

Another sub-theme concerning local settlement is outside businesses coming to the village for a few months each year, making profits in peak season at the expense of local businesses. They are then perceived to be leaving the village without contributing to the community:

"I am not happy about those who are here three to four months, and do not have residential addresses in Geiranger or Stranda municipality... So be it, but the social part is absent. We just see them passing by, none of them contribute to (social activities like) skiing, bazaars or choirs. The biggest challenge (related to sustainability) is people. There is nothing wrong with those "surfing" and making money only in summer, but maybe they should stay half of the year... How can we develop an area or village when we're only 200 inhabitants?" (Local resident and businessperson, own addition in brackets)

Other informants point at what needs to be done to increase the local population. Plots for housing are mentioned above. Extending the tourist season and creating local jobs are closely related to the main theme of attracting new inhabitants. Several of the stakeholders point to the need to extend the season. The two months from mid-June to mid-August have traditionally been the peak season. In the last years, prior to the COVID-19 situation, the season has been extended to last from May to the end of September in the village of Geiranger. The main reason for this is the global trend of increasing tourism, in combination with the fact that Norway is perceived as a safe and attractive tourism destination. A goal for single enterprises and for the area as a whole has thus been to further extend the season to build a basis for all-year-round businesses. This is also reflected in the local masterplan for tourism, which was developed in a participatory process:

\section{"Geiranger 2030}

The overriding goal is to create a vibrant local community through sustainable year-round tourism." [69]

The aim of local all-year-round jobs is another version of the same sub-theme. Year-round jobs are seen as an important stepping-stone on the way to sustainability for the community, and is formulated like this by one of the local businesspersons:

"There may be too much traffic in July. There is an incredible interest during the Norwegian holiday weeks. There are huge contrasts between 20 July and 1 October. Everyone wants to spread the traffic, but people have holidays in summer... . The whole village loses money from 1 October to 1 May. If we fail to make money during summer so that we can keep the businesses open in winter, the snowball will roll the wrong way. Now we earn reasonably well in summer, because of this we can keep open in winter. Accountants ask why we do not just close in winter, but we want the village to be alive all year round. We will continue to try, it is a goal for us living here." (Interview with a local resident and businessperson.) 


\subsubsection{Traffic}

Issues related to traffic are the second most important theme related to sustainability in the interviews. Also, in this case, the approach of the stakeholders differs. There is considerable focus on capacity expansion to solve the congestion issues-for instance, through better roads and more parking spaces. Several different interconnected measures are mentioned. One interviewee seemed to debate with himself about different measures raised in the local sustainability and traffic debate:

"I would think that, for example, for cruise lines to survive in the future they must change to more environmentally friendly ways. They (Geiranger) may have to get a new cruise quay in the long run. Remote parking (one of the solutions discussed) is not possible, I do not believe in it, the cars must be able to drive through here. If there was a tunnel (...), we could then have electric buses so that people could drive down here. I do not envision now that we can start with remote parking. If you are going to (drive) through and you cannot park in the valley... (It is) not a simple question. There will probably be more electric cars eventually ... we do not have a charging station in the center, (then the visitor) must drive to the Fjord Center to charge a car. I am thinking that Geiranger cannot pioneer everything, we are so few inhabitants here, all inhabitants here are needed." (Local resident and businessperson, own addition in brackets.)

A recurring theme is the redistribution of tourists in time and space. One of the stakeholders expresses that sustainable development is to:

".. reduce the number of tourists during the peak summer months and spread tourism throughout the year - at least spring and autumn season." (Interview with local inhabitant and businessperson.)

Others claim that a shift from mass tourism to more focus on individual travelers with a higher willingness to pay would be a solution to the traffic problem.

"I am thinking that if we had been clever enough to get tourists all year, especially during the shoulder season... that focus on mass tourism was not so strong, that we had a better product for the individual travelers ...." (Interview with local inhabitant and businessperson.)

There are also other sub-themes related to traffic. New technologies as a solution to the emission problem is one example, restrictions on number of visitors both on sea and land is another.

\subsection{Emergent Patterns}

Emergent patterns are about the patterns that seem to come up from the comparison of interviews along themes, viewpoints and emphasis [63]. Two marked patterns emerging from the data are presented below.

\subsubsection{An Anthropocentric Worldview}

An anthropocentric worldview is vividly present in the interviews. The natural environment is frequently turned into a means to human benefit in the interviews:

"Interviewer: Would you say that you and/or your organization have interests related to how the natural environment develops in the Geirangerfjord and surrounding areas?

Interviewee: I'd say that's what they (tourism enterprises) live from.

Interviewer: In what way?

Interviewee: ... . people come here to experience the area, silence, tranquility, the same as in 1886, it is the main reason why people travel from home and spend a lot of money ... " (Interview with public official related to Geiranger. Own addition in brackets) 
The focus is straight away shifted from nature itself to nature as a basis for tourism and business. In this case, the wording of the question might have led the informant in such a direction, but the anthropocentric viewpoint is a pervasive theme present all through the interviews. For instance, asked openly about what the challenges to sustainability are, there is a similar turn from another informant:

"I think I would rank environmental challenges as number one, and by this I mean both on land and in the fjord, because it creates these images of Geiranger, this with the blue smog- that we are approaching a level of pollution that is harmful to health. Then preserving the cultural landscape as number two, it is dependent on farmers who cultivate the land. ... So, one, the environment, two, the cultural landscape." (Interview with public official related to Geiranger area.)

Or this passage, when a local stakeholder is asked about what sustainability entails:

"When tourists write letters on their own ... (about crowding/air pollution) ... we live after all off the market, (then we) must do something. We have received NOK 2 million to develop a master plan for Geiranger to preserve world heritage, nature and cultural qualities." (Interview with public official related to the Geiranger area. Own addition in brackets)

The quotes from the interviews illustrate informants stating that the natural environment is important to them, because it is important to tourists, which again is important to businesses. The anthropocentric viewpoint is also present in various documents. One example is the letter of assignment from the Norwegian Maritime Authority to the Norwegian Environment Agency to reduce emissions from cruise ships in the world heritage fjords because of "the environment and health" and because, among other considerations:

"The ship calls also periodically cause aesthetic pollution consisting of visible clouds consisting of particles, NOx, sulfur oxides (SOx) and water vapor." [70]

The anthropocentric world view is also clearly present in the Outstanding Universal Value of the world heritage site. Already in the opening sentence of the brief synthesis it is stated:

"The starkly dramatic landscapes of Geirangerfjord and Nærøyfjord are exceptional in scale and grandeur in a country of spectacular fjords .... .». [71]

The focus is on how the landscape appears-for humans. It is also worth to bear in mind that even the concept "environment" refers to the environment of humans and is basically a human-centered concept.

\subsubsection{The Interconnectedness of Issues—With Settlement as the Endpoint}

The stakeholders appear to have a general knowledge about the term sustainability and of what it implies. Some also mention this directly when presenting their perception of sustainability:

"Hm, I do not know .... where you can leave as few traces as possible, but at the same time have a basis for thriving and living" (Interview with public official and regional resident.)

A more conspicuous discovery is, however, how few of the informants point to this balance in their perceptions of sustainability. Rather, the balance appears to be replaced by causal links. For instance, one stakeholder sums up sustainability in his own written words like this:

"Tourism = business = making a living and developing the community. 600-1000 inhabitants (as a goal)." (Questionnaire answer in writing from local resident and businessperson. Own addition in brackets.)

In addition, and as can be seen from the statement above, settlement seems to be the end point of a sustainability chain of logic. These two statements illustrate this point: 
"(Sustainability is ... ) 1. Year-round tourism, year-round workplaces. 2. Opportunity to find a place to live - to have access to labor, to be able to run the business all year. Then the rest will go by itself." (Interview with regional official. Own addition in brackets.)

"... Want it to be financially sustainable for businesses, while still taking care of natural qualities. That Geiranger as a community still has a social life. All year round jobs." (Interview with regional resident and official.)

Such a chain of perceived sustainable development seems also to be the logic underlying the importance of an extension of the tourist season. The aim of such an extension is to attract new citizens to the local community:

"To reduce the number of tourists in the peak of summer, spread visitation throughout the year, at least spring and autumn season... Creating the basis for a larger proportion of year-round residence that can provide a "caretaker company"-locals who can take care of what is necessary to take care of in the area. "(Interview with local resident and businessperson.)

\subsection{WINT Analysis—What Is Not There}

So far, we have been looking into themes and patterns that are present in the interviews. To give additional depth to the analysis, we are in the following presenting issues that are not explicitly present in the data. Potentially such a WINT analysis may include many issues. To pick topics, we therefore concentrated on what we found to be the most conspicuous findings based on our knowledge about the discourse on sustainability globally and locally. What is strikingly missing?

A prominent theme in the local sustainability discourse is air pollution, or rather the visible condensation clouds above the fjord landscape. Tourist and tour operator complaints have been important in raising the issue. The search for solutions has been fronted by the local World Heritage administration, but has also been taken up by regional and national authorities [58]. Knowledge about the problem has been built through research and development projects, courses and seminars. Subsequently, measurements have shown that the concentration of small particles in the air $\left(\mathrm{PM}<2.5 \mu \mathrm{g} / \mathrm{m}^{3}\right)$ can be dangerous to health $[54-57,72]$. Seen in this perspective, it is surprising that this discourse is not prevalent in the interviews about sustainability.

Furthermore, local challenges that are not visible seem to fall out of mind and are not mentioned in the interviews. Pollution of the sea is one such example. While receiving some attention in the local sustainability discourse, nothing is mentioned about this in the interviews. Having in mind that the fjord is the main attraction for the visitors, and that the fjord landscape is the basis of the World Heritage status, this is surprising. Using a wider geographical approach, it seems that issues that are out of reach to the stakeholders also fall out of their perceptions of sustainability. Issues that come to mind are, for instance, climate change and plastic waste. Both are huge issues in national and international sustainability discourse, but barely mentioned in the interviews.

Seen in the perspective of sustainability as a balance between economic, social and environmental values, surprisingly little attention is given to this balance as such, and to economic and environmental issues. Only one person involved in tourism, but not living in the village, addressed economic issues directly when encouraged:

"The financial results have to be positive. Most preferably positive enough to expand (business). If we are unable to have positive financial results, most things will stop by themselves." (Interview with business representative. Own addition in brackets.)

There are very few quotes with such a clear economic reference. Most interviewees talk about business as a means to an end, about businesses to create jobs and subsequently local year-round settlement.

When scrutinizing the role of the natural environment in the stakeholders' perception of sustainability, there is strong agreement among them that they have a strong interest to preserve it. 
The issue of nature preservation is, however, not a prominent theme and usually only arises when the interviewer encourages the informant to bring up environmental issues. Then again, if raised, nature is perceived as a means to serve human needs. The latter is further elaborated in the previous section about the anthropocentric worldview. Interestingly enough, the issue of world heritage status is also almost absent in the interviews and is only brought up by stakeholders working directly with world heritage on a daily basis.

\subsection{Comparison across Groups}

Stakeholders have diverse and multiple roles as citizens, neighbors, employees, shop owners, parents, children, etc. This is not new [73,74]. This overlap of roles seems particularly prevalent in the Geiranger case, where many of the main stakeholders and interviewees are both inhabitants of a small community, and at the same time have an official role, and a business interest. It is also a fact that which role is played out is influenced by context. A couple of stakeholders reflected on this mix of roles and how it influences answers in the interview:

"(Sustainability entails ... ) the solutions that first and foremost take care of the natural environment, that must be my role, I am less concerned if (the solutions are) financially sustainable. This might have been different if I was answering as a private person ...." (Interview with public representative. Own addition in brackets.)

The overlap of roles thus makes it difficult to know which role is actually playing out in the interview situation. To divide stakeholders into groups is therefore demanding, and we have chosen to make several types of distinctions in the analysis. To make the presentation of the main findings in the following easier, we are only using two of them: the first divide is based on place of residence, namely local, regional or national/international. The second divide is based on a common division in different types of stakeholder analysis, the divide between tourism business, public administration and inhabitants. Based on the abovementioned role mix of the stakeholder group, the last divide is not straightforward, since the interviewees were not asked to answer on behalf of a particular role in the interview.

The following figures are meant to illustrate main similarities and differences between groups. The findings are supported in other ways in the main body of the text from the data collection. It is important to have this in mind, as using percentages for such a low number of respondents can be misleading.

The comparative analysis highlights three important findings. Firstly, there are major differences of perceptions of sustainability across the divide of place of residence. This is particularly visible analyzing stakeholders' views on increasing the number of inhabitants. The closer to the village of Geiranger the stakeholder live, the more focus is on this theme as the main ingredient of sustainable development. While 13 out of $15(87 \%)$ of local residents mention this as an important ingredient of sustainable development, 4 out of $6(67 \%)$ stakeholders regionally and only 1 out of $7(14 \%)$ of the stakeholders residing outside the region or internationally mention this. The point is illustrated in Figure 2.

Secondly, place of residence seems to be a stronger background factor influencing stakeholder perceptions than other divides. This is illustrated in Figure 3. At first glance, there appears to be a difference of focus on number of inhabitants between tourism businesses, inhabitants and public management (lower part of the figure). Among tourism businesses, 6 out of 14 (43\%) mention this aspect, while 4 out of $5(80 \%)$ of the local inhabitants mention the same.

This divide however disappears when looking more thoroughly at the tourism business group (upper part of the figure). Informants residing locally and representing tourism businesses have just as much focus on increasing number of inhabitants as the group of local inhabitants without such business interest; $80 \%$ (4 out of 5 ) mention this theme. By comparison, of national and international 
tourism businesses, only one out of five mention the theme (20\%). Of the regional businesspersons, one out of four mention the same (25\%).

\section{Percent of group mentioning increase of inhabitants by place of residence}

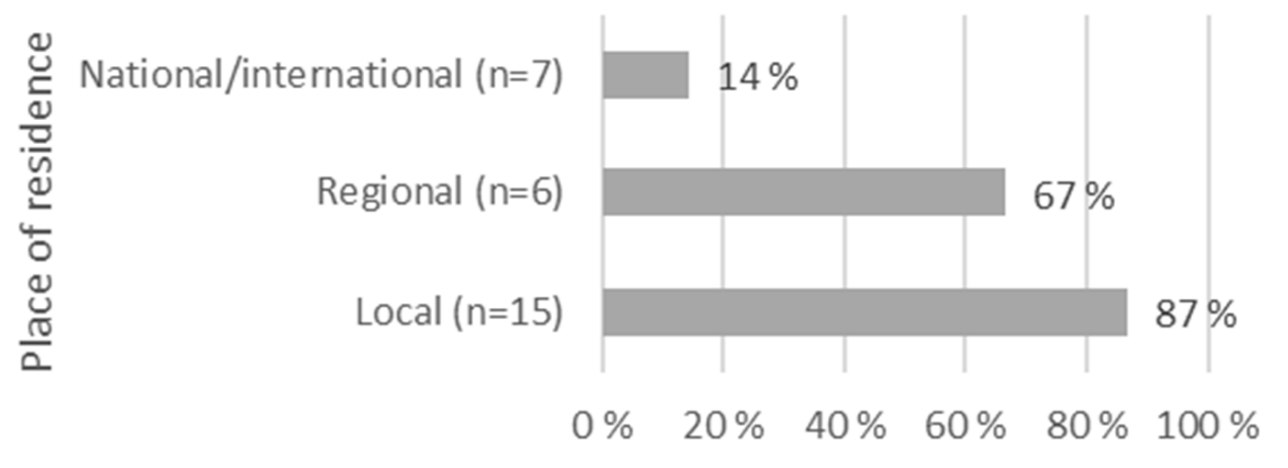

Figure 2. Percentage of each group of stakeholders mentioning increase of inhabitants as an ingredient of sustainable development for the area-depending on place of residence (Total $N=28$ ).

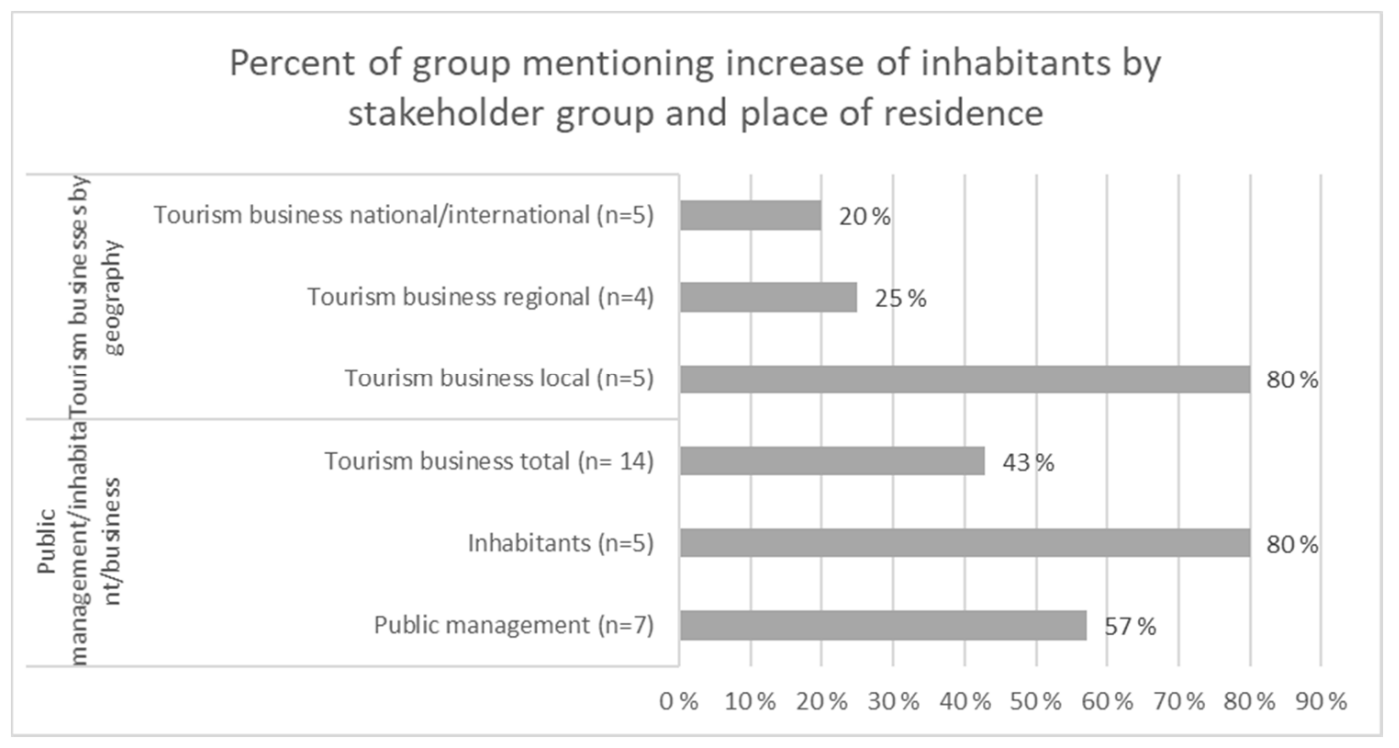

Figure 3. Percentage of each group of stakeholders mentioning increase of inhabitants (lower part). Percent of tourism businesses divided by place of residence (upper part) mentioning the same ( $N$ total $=26, N$ total business group $=14$ ).

Thirdly, scrutinizing the data material in search for the natural or economic dimensions of sustainability, the main impression is that no group of stakeholders is particularly focused on any of them (illustrated in Figure 4). The public managers group seems to have more focus on nature aspects than other groups ( 2 out of 7, 29\% mention this). The group of public managers includes protected area managers and people representing the world heritage and environmental organizations. The stakeholders seem to have even less focus on economy and profit. Only one stakeholder representing the tourism businesses is directly mentioning economy and profit at all in any of the interviews ( 1 out of $14,7 \%)$. 


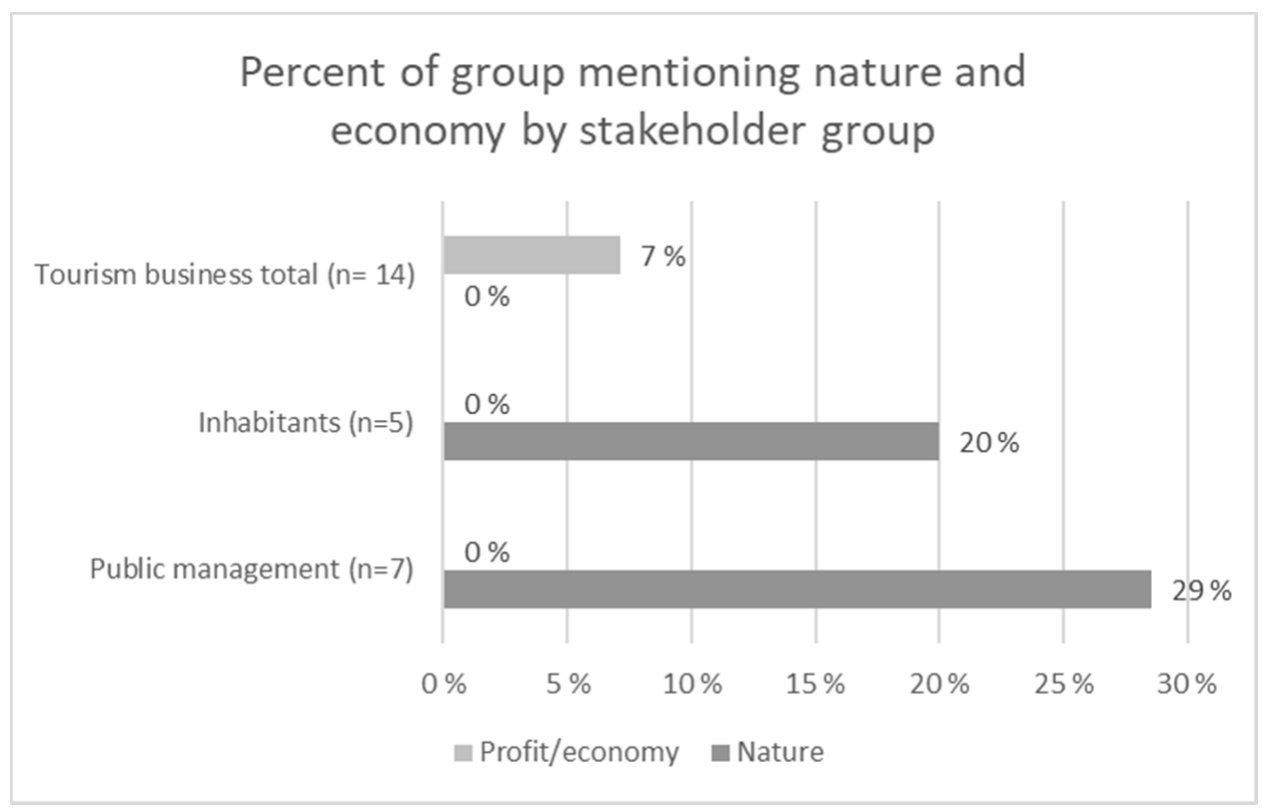

Figure 4. Percentage of each group of stakeholders mentioning nature and economy as an ingredient of sustainable development for the area $(N$ total $=26)$.

\section{Discussion}

As shown above, the main themes of the stakeholders' perceptions of sustainable development in the Geiranger World Heritage area are to increase the number of inhabitants in the community and issues related to traffic. The latter includes subthemes like crowding and congestion, air pollution and transport accessibility. Furthermore, there are two conspicuous patterns of stakeholder views: firstly, an anthropocentric worldview; and secondly, perceptions seem to be put together in a coherent line of reasoning. WINT analysis further reveals that issues out of sight and reach disappear in interviewees' perceptions of sustainability. These issues are, for instance, air pollution, climate change and sea pollution. The value of the economy and nature by and for itself are not included in their immediate perception of sustainability, either. Analyses across groups further show that while place of residence influences perceptions of sustainable development in the area, other group memberships do not seem to have a substantial effect.

More broadly speaking, we have three main findings. Firstly, the interviewed stakeholders seem to be aware of the official definition of sustainability. When encouraged, stakeholders mention both social, environmental and economic aspects related to sustainability, and some refer to the balance between the three. The findings thus do not oppose the view that there is a form of consensus about what sustainability means in the public sphere $[1,4,6]$. However, the priorities of local stakeholders do not include all three aspects of sustainability equally. Increasing the local population is of greater importance than the environmental and economic aspects. Also, the other main theme related to traffic is not predominantly an ecological issue. The emphasis of the stakeholders is on crowding, congestion and mobility of tourists and locals. Even with an environmental indicator like air pollution, stakeholders point out that air pollution is problematic, not so much for environmental reasons, as for the impact it has on the experience of tourists and thereby the image of the Geiranger area as a tourist destination. The perceptions of sustainability locally thus seem to reflect a hierarchy of values with main emphasis on social values, rather than a balance between the economy, nature and society (illustrated in Figure 5).

Secondly, the results strengthen the argument that stakeholders' perceptions of sustainability vary according to context $[7-9,14,15,38]$. More specifically, in this context, the local stakeholders' perceptions of sustainability appear as a sustainability chain of logic, illustrated in Figure 6 . The environment is precious because it is important for tourism and serves as a basis for jobs and economic viability, 
since nature-based tourism is the basis of the economy. The overarching goal is to attract more inhabitants to the community. In line with this, geographical scale seems to influence the emphasis on different aspects of sustainability. For instance, the sustainability chain of logic presented above is quite similar for many of the individuals, but is much more prominent among stakeholders living in the Geiranger area.

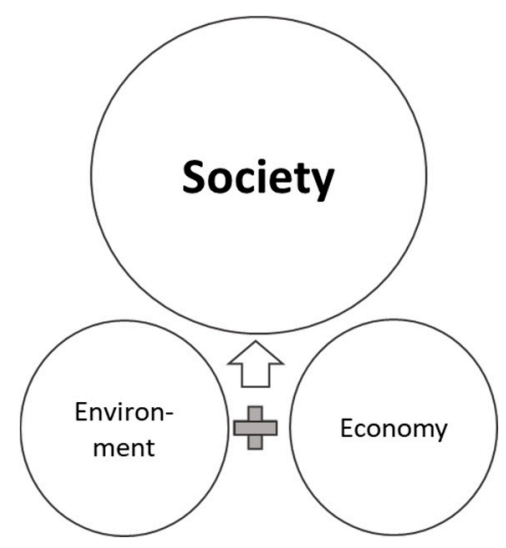

Figure 5. Hierarchy of components of sustainability by stakeholders. Source: own figure.

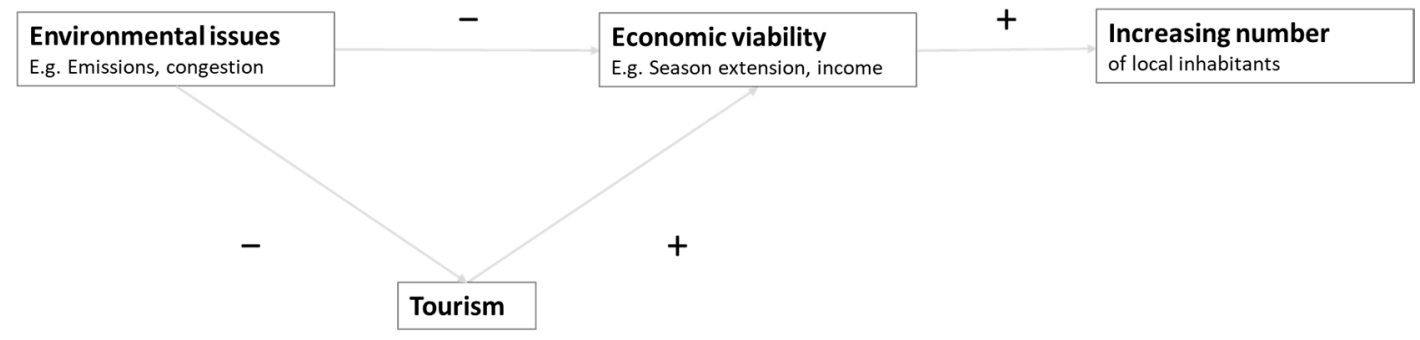

Figure 6. The stakeholders' sustainability chain of logic. Source: own figure.

Thirdly, our study supports the findings by several studies $[8,9,15,37]$ that sustainability issues perceived as most important by stakeholders are topics very close to people's lives. They are visible and traceable to stakeholders. In addition, it seems like interviewees' current experiences are important to their expressed perceptions of sustainability.

How is this to be interpreted? This is a single, explorative case study and thus does not create a strong basis for generalizations. This being said, given the literature on human perception [10,12,13,29], it is not surprising that perceptions of sustainability differ. These discrepancies are, however, undercommunicated and not well understood. A better understanding can be crucial to understand local dynamics in the strive for sustainability.

More surprising, from the perspective of human perception, is the fact that the perceptions of the stakeholders broadly speaking are quite similar. They are focused on social issues, not economic and ecological ones. Stakeholders perceive the concept from a quite similar anthropocentric viewpoint. Through perceptions' interplay with values and beliefs [10,29], these findings may lead to the conclusion that social issues are of higher value than economic and environmental concerns. Such likeness could stem from similarities of the perceptual system of humans [10]. If this is the case, then such findings have major implications for how to approach and achieve the balance of sustainability $[1,4,22]$. Taking this one step further, the findings support the findings of O'Toole et al. [15], indicating that the most prominent social concern of the community constitutes the main issue of local perceptions of sustainability. If generalizable, the immediate local context of the stakeholders can be expected to be the main issue in local inhabitants' perception of sustainable development in communities. The "sustainability-chain of logic" might be a key to understanding local mechanisms of sustainability. 
The fact that place of residence seems to be the strongest determinant of perceptions, in our case much stronger than for instance occupational background, is in line with literature which shows that physical space and placement are strong determinants of perceptions [10]. Put together with the finding that stakeholders seem to accentuate issues that are close to their lives, and that issues outside the local inhabitants' sight and sphere of influence are not a part of local perceptions of sustainability, this could be indications of a pattern of perceptions of sustainability.

\section{Conclusions}

This paper contributes to a clearer understanding of perceptions of sustainability in local communities. It shows on the one hand that findings are consistent with an understanding of perceptions of sustainability shaped in complex individual and group processes and through discourses on different geographical levels. On the other hand, the perceptions are surprisingly similar at the local level. Through interplay with attitudinal variables and context, perceptions thus may influence decisions and actions in the local community and thereby the global strive for sustainability.

In this way, this article adds to the scarce existing literature on perceptions of the concepts of "sustainable development" and "sustainability". To be able to generalize about these perceptions with any certainty, further research should compare across communities and geographical levels. There is also a need to look more thoroughly into the mechanisms creating the local perceptions and to understand what these perceptions mean to local actions in a sustainability perspective.

Furthermore, the findings have implications for sustainable policies. They indicate that there is a need for further contextualization of what constitutes sustainability in local settings, and following from this, also a contextualization of policies. Research has shown that involvement and perceived benefits are necessary for support of environmental challenges [14,39]. Giving attention to local concerns related to sustainability should therefore be an integral part of sustainable policies. There is a need to focus both on global and local sustainability concerns for the global agenda for change to be realized.

Author Contributions: Conceptualization, E.R.Y.; Data curation, E.R.Y.; Formal analysis, E.R.Y. and N.H.; Funding acquisition, E.R.Y.; Investigation, E.R.Y.; Methodology, E.R.Y.; Project administration, E.R.Y. and N.H.; Software, E.R.Y.; Supervision, N.H.; Visualization, E.R.Y.; Writing-original draft, E.R.Y. and N.H.; Writing-review \& editing, E.R.Y. and N.H. All authors have read and agreed to the published version of the manuscript.

Funding: This research is funded by the Research Council of Norway (Norges Forskningsråd) registered with project name: "An integrated sustainability appraisal methodology for transportation in rural tourism pressure areas" (SUSTRANS) Project number: 267887.

Acknowledgments: The authors would like to thank project partners in SUSTRANS for valuable contributions to the research.

Conflicts of Interest: The authors have no conflict of interest.

\section{References}

1. United Nations. Report of the World Commission on Environment and Development: Our Common Future; United Nations: New York, NY, USA, 1987.

2. Kruja, D.; Alkida, H. Comparisons of stakeholders' perception towards the sustainable tourism development and its impacts in Shkodra Region (Albania). Turizam 2010, 14, 1-12. [CrossRef]

3. Timur, S.; Getz, D. Sustainable tourism development: How do destination stakeholders perceive sustainable urban tourism? Sustain. Dev. 2009, 2009, 220-232. [CrossRef]

4. Vermeulen, W.J.V. Substantiating the rough consensus on concept of sustainable development as point of departure for indicator development. In Routledge Handbook of Sustainability Indicators; Bell, S., Morse, S., Eds.; Routledge: Abingdon, UK, 2018.

5. UNESCO. Policy Document for the Integration of a Sustainable Development Perspective into the Processes of the World Heritage Convention. In Proceedings of the General Assembly of States Parties to the World Heritage Convention, Paris, France, 18-20 November 2015.

6. UN General Assembly. Transforming Our World: The 2030 Agenda for Sustainable Development; Res. 70/1; UN General Assembly: New York, NY, USA, 2015. 
7. Robinson, J. Squaring the circle? Some thoughts on the idea of sustainable development. Ecol. Econ. 2004, 48, 369-384. [CrossRef]

8. Macnaghten, P.; Jacobs, M. Public identification with sustainable development. Investigating cultural barriers to participation. Glob. Environ. Change 1997, 7, 5-24. [CrossRef]

9. Macnaghten, P.; Grove-White, R.; Jacobs, M.; Wynne, B. Public Perceptions and Sustainability in Lancashire: Indicators, Institutions, Participation; Lancashire County Council: Preston, UK, 1995.

10. Lueg, C.P. Characteristics of human perception and their relevance when studying information behavior. J. Doc. 2014, 70, 562-574. [CrossRef]

11. Greenwald, A.G.; Banaji, M.R. Implicit social cognition: Attitudes, self-esteem, and stereotypes. Psychol. Rev. 1995, 102, 4-27. [CrossRef]

12. Parker, A.J.; Newsome, W.T. Sense and th single neuron: Probing the physiology of perception. Annu. Rev. Neurosci. 1998, 21, 227-277. [CrossRef]

13. Freeman, W.J. The physiology of perception. Sci. Am. 1991, 264, 78-85. [CrossRef]

14. Imran, S.; Alam, K.; Beaumont, N. Environmental orientations and environmental behaviour: Perceptions of protected area tourism stakeholders. Tour. Manag. 2014, 40, 290-299. [CrossRef]

15. O'Toole, K.; Wallis, A.; Mitchell, B. Local perceptions of sustainability indicators: Issues of scale and implications for management. Rural Soc. 2014, 16, 25-46. [CrossRef]

16. Labadi, S. UNESCO, World Heritage, and sustainable development: International discourses and local impacts. In Collision or Collaboration. Archaeology Encounters Economic Development; Gould, P.G., Pyburn, K.A., Eds.; Springer International Publishing: Cham, Switzerland, 2017; pp. 45-60. [CrossRef]

17. McDonald, F.V. Developing an Integrated Conceptual Framework of Pro-Environmental Behavior in the Workplace through Synthesis of the Current Literature. Administrative Sci. 2014, 2014, 276-303. [CrossRef]

18. Yttredal, E.R.; Babri, S.; Diez, M. Antall Besøkende og Kjøretøy i Geirangerområdet 2018; Notat-nr. 4/2019; Høgskulen i Volda: Volda, Norway, 2019.

19. Mebratu, D. Sustainability and sustainable development: Historical and conceptual review. Environ. Impact Assess. Rev. 1998, 18, 493-520. [CrossRef]

20. Lumley, S.; Armstrong, P. Some of the nineteenth century origins of the sustainability concept. Environ. Dev. Sustain. 2004, 2004, 367-378. [CrossRef]

21. Heinberg, R. What Is Sustainability? Post Carbon Institute: Santa Rosa, CA, USA, 2010.

22. Griggs, D.; Stafford-Smith, M.; Gaffney, O.; Rockström, J.; Öhman, M.C.; Shyamsundar, P.; Steffen, W.; Glaser, G.; Kanie, N.; Noble, I. Sustainable development goals for people and planet. Nature 2013, 495, 305-307. [CrossRef]

23. Ciegis, R.; Ramanauskiene, J.; Martinkus, B. The Concept of Sustainable Development and its Use for Sustainability Scenarios. Inz. Ekon. Eng. Econ. 2009, 2009, 28-37.

24. Steffen, W.; Richardson, K.; Rockström, J.; Cornell, S.E.; Fetzer, I.; Bennett, E.M.; Biggs, R.; Carpenter, S.R.; De Vries, W.; De Wit, C.A.; et al. Planetary boundaries: Guiding human development on a changing planet. Science 2015, 347. [CrossRef]

25. Rockström, J.; Steffen, W.; Noone, K.; Persson, A.; Chapin Iii, F.S.; Lambin, E.; Lenton, T.M.; Scheffer, M.; Folke, C.; Schellnhuber, H.J.; et al. Planetary boundaries: Exploring the safe operating space for humanity. Ecol. Soc. 2009, 14. [CrossRef]

26. Rockström, J.; Steffen, W.; Noone, K.; Persson, Å.; Chapin, F.S.; Lambin, E.F.; Lenton, T.M.; Cheffer, M.; Folke, C.; Institute of Arctic Biology University of Alaska Fairbanks; et al. A safe operating space for humanity. Nature 2009, 461, 472-475. [CrossRef] [PubMed]

27. Aall, C. Sustainable Tourism in Practice: Promoting or Perverting the Quest for Sustainable Development? Sustainability 2014, 2014, 2562-2583. [CrossRef]

28. APA Dictionary of Psychology. Perception. Available online: https://dictionary.apa.org/perception (accessed on 24 August 2020).

29. Dunham, Y.; Banaji, M.R. Platonic blindness and the challenge of understanding context. In The Mind in Context; Mesquita, B., Feldman Barrett, L., Smith, E.R., Eds.; The Guilford Press: New York, NY, USA, 2010.

30. Haidt, J. Chapter 53: The emotional dog and its rational tail: A social intuitionist approach to moral judgment. In Reasoning. Studies of Human Inference and its Foundations; Adler, J.E., Rips, L.J., Eds.; Cambridge University Press: Cambridge, UK, 2008. 
31. Michel, A. Cognition and Perception: Is There Really a Distinction. Available online: https:// www.psychologicalscience.org/observer/cognition-and-perception-is-there-really-a-distinction (accessed on 24 August 2020).

32. Tversky, A.; Kahneman, D. The framing of decisions and the psychology of choice. Science 1981, 211, 453-458. [CrossRef]

33. Stangor, C.; Jhangiani, R.; Tarry, H. Principles of Social Psychology, 1st ed.; BCcampus OpenEd: Minneapolis, MN, USA, 2014; Available online: https://opentextbc.ca/socialpsychology/ (accessed on 20 August 2020).

34. Erdelez, S. Investigation of intormation encountering in the controlled research environment. Inf. Process. Manag. 2004, 40, 1013-1025. [CrossRef]

35. Mack, A. Inattentional blindness. Looking without seeing. Curr. Dir. Psychol. Sci. 2003, 12, 180-184. [CrossRef]

36. Pearson, C.J. Sustainability: Perceptions of problems and progress of the paradigm. Int. J. Agric. Sustain. 2003, 1, 3-13. [CrossRef]

37. Jones, N.; Malesoios, C.; Aloupi, M.; Priokaki, M.; Tsalis, T.; Hatziantoniou, M.; Dimitrakopoulos, P.G.; Skouloudis, A.; Holtvoeth, J.; Nikolaou, I.; et al. Exploring the role of local community perceptions in sustainability measurements. Int. J. Sustain. Dev. World Ecol. 2019, 26, 471-483. [CrossRef]

38. Tiani, A.M.; Charnacle, J.-M.B. Simple criteria and indicators to uncover and negotiate local perceptions on sustainability. For. Trees Livelihoods 2007, 17, 3-21. [CrossRef]

39. Törn, A.; Siikamäki, P.; Tolvanen, A.; Kaupplila, P.; Rämet, J. Local people, nature conservation and tourism in northeastern Finland. Ecol. Soc. 2008, 13, 8. [CrossRef]

40. Campbell, S.J.; Kartawijaya, T.; Yulianto, I.; Prasetia, R.; Clifton, J. Co-management approahes and incentives improve management effectiveness in the Karimanjawa National Park, Indonesia. Mar. Policy 2013, 41, 72-79. [CrossRef]

41. Novelli, M.; Scarth, A. Tourism in protected areas: Integrating conservation and community development in Liwonde National Park (Malawi). Tour. Hosp. Plan. Dev. 2007, 4, 47-73. [CrossRef]

42. Sekhar, N.U. Local people's attitudes towards conservation and wildlife tourism around Sariska Tiger Reserve, India. J. Environ. Manag. 2003, 69, 339-347. [CrossRef] [PubMed]

43. Sirivongs, K.; Tsuchiya, T. Relationship between local residents' perceptions, attitudes and participation towards national protected areas: A case study of Phou Khao Khouay National Protected Area, central Lao PDR. For. Policy Econ. 2012, 21, 92-100. [CrossRef]

44. Stern, P.C. Toward a coherent theory of environmentally significant behavior. J. Soc. Issues 2000, 56, 407-424. [CrossRef]

45. Stern, P.C.; Dietz, T. The value basis of environmental concern. J. Soc. Issues 1994, 50, 65-84. [CrossRef]

46. Amérigo, M.; Aragonés, J.I.; Frutos, B.D.; Sevillano, V.; Cortés, B. Underlying dimensions of ecocentric and anthropocentric environmental beliefs. Span. J. Psychol. 2007, 10, 97-103. [CrossRef] [PubMed]

47. Inkpen, R.; Baily, B. Environmental beliefs and their role in environmental behaviours of undergraduate students. J. Environ. Stud. Sci. 2020, 10, 57-67. [CrossRef]

48. Juvan, E.; Donicar, S. The attitude-behaviour gap in sustainable tourism. Ann. Tour. Res. 2014, 48, 76-95. [CrossRef]

49. Juvan, E.; Dolnicar, S. Measuring Environmentally Sustainable Tourist Behaviour. Ann. Tour. Res. 2016, 59, 30-44. [CrossRef]

50. Arnberger, A.; Eder, R.; Allex, B.; Sterl, P.; Burns, R.C. Relationships between national-park affinity and attitudes towards protected area management of visitors to the Gesaeuse National Park, Austria. For. Policy Econ. 2012, 19, 48-55. [CrossRef]

51. Carrus, G.; Bonaiuto, M.; Bonnes, M. Environmental concern, regional identity, and support for protected areas in Italy. Environ. Behav. 2005, 37, 237-257. [CrossRef]

52. Davis, J.L.; Green, J.D.; Reed, A. Interdependence with the environment: Commitment, interconnectedness, and environmental behavior. J. Environ. Psychol. 2009, 29, 173-180. [CrossRef]

53. Statistics Norway. 04317: Grunnkretsenes Befolkning (G) 1999-2019. Available online: https://www.ssb.no/ statbank/table/04317/ (accessed on 12 September 2019).

54. Löffler, J. Annual Scientific Report 2019; University of Bonn: Bonn, Germany, 2019.

55. Löffler, J. Annual Scientific Report 2018; University of Bonn: Bonn, Germany, 2018.

56. Löffler, J. Annual Scientific Report 2017; University of Bonn: Bonn, Germany, 2017. 
57. Löffler, J. Annual Scientific Report 2016; University of Bonn: Bonn, Germany, 2016.

58. Sjøfartsdirektoratet. Utslipp til Luft og Sjø fra Skipsfart i Fjordområder med stor Cruisetrafikk; Sjøfartsdirektoratet: Haugesund, Norway, 2017.

59. Lange, O.R. Ny turistrapport: Advarer mot livsfarlig sommerluft i den norske turistperlen. Dagbladet. Available online: https://www.dagbladet.no/tema/advarer-mot-livsfarlig-sommerluft-i-den-norske-turistperlen/69563089 (accessed on 3 March 2020).

60. Lange, O.R. Cruiseverstingene dropper norske fjordperler etter dette. Dagbladet. Available online: https: //www.dagbladet.no/tema/cruiseverstingene-dropper-norske-fjordperler-etter-dette/71391279 (accessed on 12 July 2019).

61. Stortingsforhandlinger. Klimatrategi for 2030-Norsk Omstilling i Europeisk Samarbeid; Meld. St. 41.; Storting: Oslo, Norway, 2016-2017.

62. Freeman, R.E. Strategic Management: A Stakeholder Approach; Pitman: Boston, MA, USA, 1984.

63. Saldaña, J. The Coding Manual for Qualitative Researchers; SAGE: Thousand Oaks, CA, USA, 2016.

64. Bhatia, V.; Flowerdew, J.; Jones, R.H. Approaches to Discourse Analysis. In Advances in Discourse Studies; Bhatia, V., Flowerdew, J., Jones, R.H., Eds.; Routledge: Abingdon, UK, 2008; pp. 1-17.

65. Fairclough, N. Critical Discourse Analysis: The Critical Study of Language, 2nd ed.; Longman: Hanlow, NSW, Australia, 2010.

66. Foucault, M. The Archaeology of Knowledge; Routledge: Cornwell, UK, 2011.

67. Lukes, S. Power: A Radical View; Macmillan: London, UK, 1974.

68. Thorsnæs, G. Norge-Bosettingsmønster. Available online: https://snl.no/Norge_-_bosettingsm\T1\onster (accessed on 20 August 2020).

69. PWC. Strategiplan Reisemål Geiranger; Stranda Kommune: Stranda, Norway, 2019.

70. Det Kongelige Klima-Og Miljødepartement. Oppdrag-Reduksjon av Utslipp fra Skip i Verdensarvfjordene; Det Kongelige Klima—og Miljødepartement: Oslo, Norway, 2017.

71. United Nations Educational Scientific and Cultural Organization (UNESCO); World Heritage Convention. West Norwegian Fjords-Geirangerfjord and Nærøyfjord. Available online: https://whc.unesco.org/en/list/ 1195/ (accessed on 3 January 2020).

72. Folkehelseinstituttet. Ny Rapport om Luftforurensning fra Cruiseskip i Geiranger; Folkehelseinstituttet: Oslo, Norway, 2018.

73. Mead, G.H. Mind, Self and Society from the Standpoint of a Social Behaviorist; Morris, C.W., Ed.; The University of Chicago Press: Chicago, IL, USA; London, UK, 1934.

74. Parsons, T. The Social System; Routledge, Taylor \&Francis Group: Abingdon, UK, 1991.

Publisher's Note: MDPI stays neutral with regard to jurisdictional claims in published maps and institutional affiliations.

(C) 2020 by the authors. Licensee MDPI, Basel, Switzerland. This article is an open access article distributed under the terms and conditions of the Creative Commons Attribution (CC BY) license (http://creativecommons.org/licenses/by/4.0/). 